\title{
Enhancement of natural radioactivity in the surrounding of a phosphate fertilizer complex in Santos basin, Brazil
}

\author{
B.P. Mazzilli, P.S.C. Silva and M.B. Nisti \\ Instituto de Pesquisas Energéticas e Nucleares, Departamento de Radioproteçao Ambiental, \\ Caixa Postal 11049, Sao Paulo, Brazil
}

\begin{abstract}
Phosphate deposits are generally characterised by enhanced radionuclides concentration compared to average natural levels. Mining and processing of phosphate ore redistribute radionuclides into final products, byproducts and solid waste (phosphogypsum). The phosphate fertiliser complex located in Santos Basin, Southwest Brazil, produces approximately 2000 tons of phosphogypsum per day, which are stockpiled and presents a potential threat to the environment. The radiological environmental impact is mainly due to the presence of ${ }^{226} \mathrm{Ra}$, ${ }^{228} \mathrm{Ra}$ and ${ }^{210} \mathrm{~Pb}$. This study aims to determine these radionuclides in 13 sediment samples from Santos estuarine system in the surrounding of phosphate plants. As the organic debris is a good adsorbent of radionuclides, total organic carbon was also determined. ${ }^{226} \mathrm{Ra}$, ${ }^{228} \mathrm{Ra}$ and ${ }^{210} \mathrm{~Pb}$ were measured by gamma spectrometry using a hiperpure Ge detector. The activity concentrations varied from $6 \pm 2$ to $44 \pm 5 \mathrm{~Bq} / \mathrm{kg}$ for ${ }^{226} \mathrm{Ra}$, from $8 \pm 3$ to $77 \pm 6 \mathrm{~Bq} / \mathrm{kg}$ for ${ }^{228} \mathrm{Ra}$ and from $<13$ to $114 \pm 21 \mathrm{~Bq} / \mathrm{kg}$ for ${ }^{210} \mathrm{~Pb}$. Statistical analyses of the results showed that three samples collected near the industries presented anomalous activity concentrations, above average values of the region. A good correlation was observed between the activity concentration and the total organic carbon in all samples analysed, exception made for the three already mentioned.
\end{abstract}

\section{INTRODUCTION}

Santos Basin, located in Southwest Brazil, comprising the counties of Santos $\left(725 \mathrm{~km}^{2}\right)$, São Vicente $\left(131 \mathrm{~km}^{2}\right)$ and Cubatão $\left(160 \mathrm{~km}^{2}\right)$, is considered the most important industrial region of São Paulo State. However, such activities also represent a potential threat to the surrounding environment $[1,2]$. Its estuarine system is responsible for deposition of a considerable amount of material, which is transported by rivers, including metals and other pollutants discharged by the local industrial activity.

The phosphate fertilizer production includes the mining and processing of phosphate ore. This phosphate ore is converted initially into phosphoric acid, which is then used as a raw material for manufacturing a variety of phosphatic fertilizers. Besides phosphoric acid, a by-product called "phosphogypsum" is formed during the so-called "wet process", when the calcium phosphate ore reacts with sulphuric acid. This by-product may crystallise in either the dihydrate $\left(\mathrm{CaSO}_{4} \cdot 2 \mathrm{H}_{2} \mathrm{O}\right)$ or hemihydrate $\left(\mathrm{CaSO}_{4} .1 / 2 \mathrm{H}_{2} \mathrm{O}\right)$ form of gypsum depending upon the operating conditions within the plant. This material contains significant quantities of impurities including phosphate, fluoride and radionuclides of the uranium and thorium-series $[3,4]$. This paper aims to determine the activity concentration of radionuclides ${ }^{226} \mathrm{Ra},{ }^{228} \mathrm{Ra}$ e ${ }^{210} \mathrm{~Pb}$ in the sediments of Santos and São Vicente estuaries.

\section{MATERIAL AND METHODS}

Sediment samples were collected by dragging in the locations depicted in Figure 1. In each location samples were collected in triplicate. Gamma spectrometry was used for the determination of ${ }^{226} \mathrm{Ra},{ }^{228} \mathrm{Ra}$ and ${ }^{210} \mathrm{~Pb}$. All sediment samples studied were prepared by drying at a temperature of $110^{\circ} \mathrm{C}$ to constant mass, ground to a grain-size of less than $250 \mu \mathrm{m}$ and finally homogenised.

For determination of radionuclides activity concentration, samples were packed in $100 \mathrm{~cm}^{3}$ polyethylene containers and sealed for about four weeks prior to measurement in order to ensure that equilibrium has been reached between ${ }^{226} \mathrm{Ra}$ and its decay products of short half-life, ${ }^{214} \mathrm{Bi}$ and ${ }^{214} \mathrm{~Pb}$. Samples were measured by using a hyper-pure germanium detector, EGNC 15-190-R from Eurisys, with $15 \%$ efficiency, during $60,000 \mathrm{~s}$. The detector was calibrated using natural soil and rock spiked with radionuclides certified by Amersham. The system background was obtained by measuring water in the same sample counting geometry for $300,000 \mathrm{~s}$. The gamma spectra obtained were analysed by using WinnerGamma program [5]. 


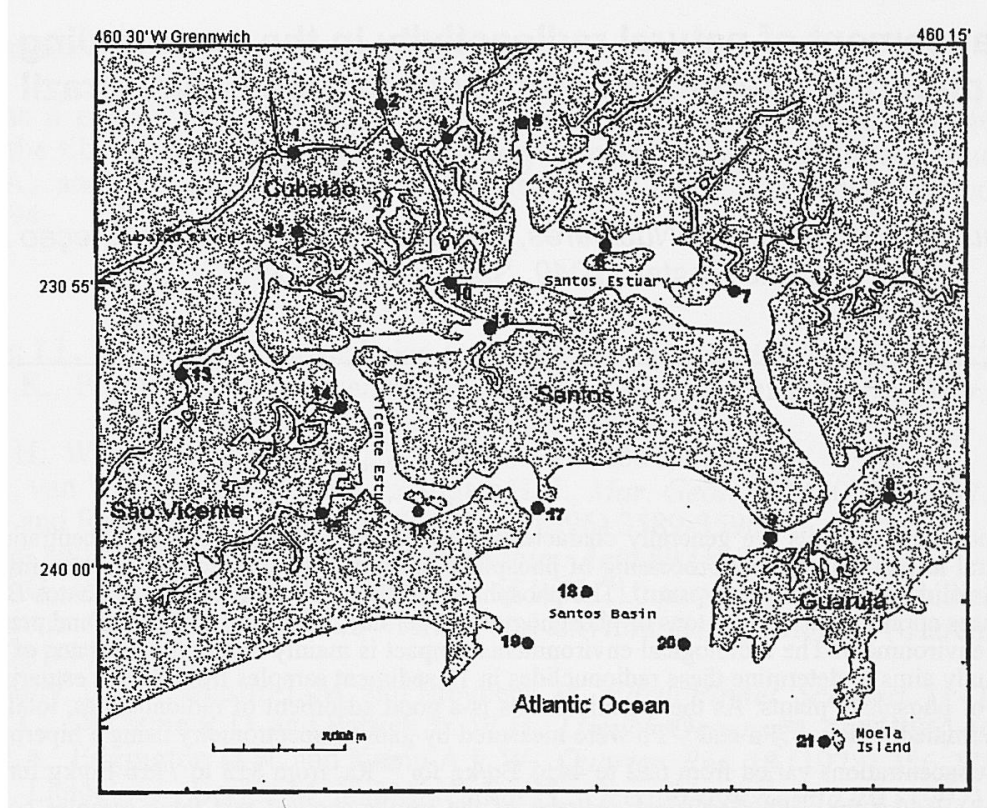

Figure 1: Schematic map of Santos and São Vicente estuary showing the sampling locations. Points not mentioned in the texl wasn't still analysed till the moment.

${ }^{226} \mathrm{Ra}$ activities were determined by taking the mean activity of three separate photopeaks of th daughter nuclides: ${ }^{214} \mathrm{~Pb}$, at $295.21 \mathrm{keV}$ and $351.93 \mathrm{keV}$, and ${ }^{214} \mathrm{Bi}$ at $609.32 \mathrm{keV}$. The ${ }^{228} \mathrm{Ra}$ content of the samples was determined by measuring the intensities of the $911.07 \mathrm{keV}$ and $968.90 \mathrm{keV}$ gamma-ray peaks from ${ }^{228} \mathrm{Ac}$. Typical lower limits of detection for gamma spectrometry were $0.17 \mathrm{~Bq} / \mathrm{kg}$ for ${ }^{26 \mathrm{Ra}}$ and $0.59 \mathrm{~Bq} / \mathrm{kg}$ for ${ }^{228} \mathrm{Ra}$, for a counting time of 50,000 seconds.

The concentration of ${ }^{210} \mathrm{~Pb}$ was carried out by measuring the activity of its low energy peak (46.54 $\mathrm{keV}$ ). Self-absorption correction was applied since the attenuation for low energy gamma rays is highly dependent upon sample composition. The approach used was modified from that suggested by Cutshall et al., 1983 [6]. According to them, the self-absorption equation may be written as:

$$
A / O=\frac{\ln \left(\frac{T}{I}\right)}{\left(\frac{T}{I}-1\right)}
$$

Where $\mathrm{O}$ is the attenuated sample output (count rate), $\mathrm{A}$ is the actual sample photon emission rate, $\mathrm{T}$ and $\mathrm{I}$ are the beam intensities transmitted through the sample and standard, respectively. The attenuated beam intensity $(\mathrm{T})$ is defined as the difference between the count rate of each sample with and without an external source containing ${ }^{210} \mathrm{~Pb}$ centred on top of the sample container. The factor I was determined by making a measurement with the same external ${ }^{210} \mathrm{~Pb}$ source placed on top of the efficiency standard. This ratio thus represents how each sample compares to the efficiency standard in terms of self-absorption. The final ${ }^{210} \mathrm{~Pb}$ activities are then obtained by substituting the relative absorption factor into the activity calculation equation, as follows:

$$
A(B q / k g)=\frac{(C-C o) \cdot f a b s}{W t \cdot \eta \cdot T \cdot \gamma}
$$

Where $\mathrm{A}$ is the sample activity, $\mathrm{C}$ and Co are the sample and background counts, Wt is the sample weight in $\mathrm{kg}$, fabs is the relative absorption factor, $\eta$ is the efficiency in $\mathrm{cps} / \mathrm{dps}, \mathrm{T}$ is the counting time in seconds and $\gamma$ is the peak intensity. The lower limit of detection obtained for ${ }^{210} \mathrm{~Pb}$ was $20.6 \mathrm{~Bq} / \mathrm{kg}$, for a counting time of 50,000 seconds. 


\section{RESULTS AND DISCUSSION}

The results obtained by gamma spectrometry are presented in Table 1 . The activity concentration varied from $6 \pm 2$ to $44 \pm 5 \mathrm{~Bq} / \mathrm{kg}$ (points 17 and 1 respectively) for ${ }^{226} \mathrm{Ra}$; from $8 \pm 3$ to $77 \pm 6 \mathrm{~Bq} / \mathrm{kg}$ for ${ }^{228} \mathrm{Ra}$ (points 17 and 1 respectively) and from $<13$ to $114 \pm 21 \mathrm{~Bq} / \mathrm{kg}$ for ${ }^{210} \mathrm{~Pb}$ (points 17 and 12 respectively). Higher concentrations were observed near Cubatão where the industrial complex is located (points 1,2 , 3 ) and in point 12. Lower concentrations were found in points $9,16,17$ and 21 . Points 8 and 9 are located in Santos estuary; points 13,14,15, 16 and 17 in São Vicente estuary; and point 21 in the ocean far away from the coast.

The concentration of ${ }^{228} \mathrm{Ra}$ (half life of 5.75 years) and ${ }^{210} \mathrm{~Pb}$ (half life of 22 years) were plotted against ${ }^{226} \mathrm{Ra}$ (half life of 1622 years) activity concentration (Figure 2). No correlation was observed between concentrations of ${ }^{210} \mathrm{~Pb}$ and ${ }^{226} \mathrm{Ra}$; whereas ${ }^{228} \mathrm{Ra}$ (from ${ }^{232} \mathrm{Th}$ series) and ${ }^{226} \mathrm{Ra}$ (from ${ }^{238} \mathrm{U}$ series) presented high correlation.

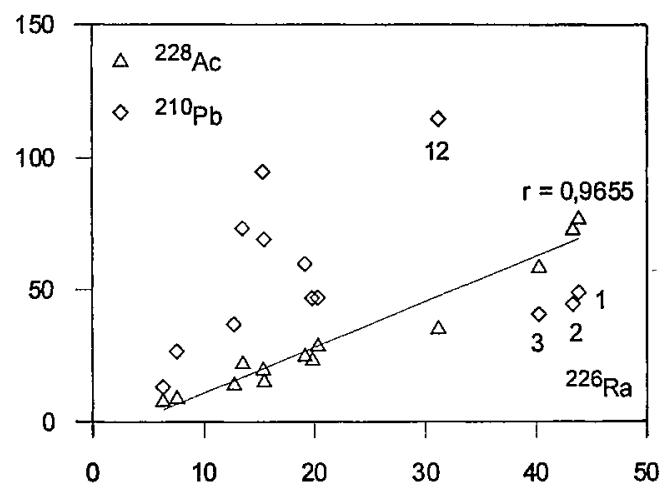

Figure 2: Activity concentration of ${ }^{228} \mathrm{Ra}$ and ${ }^{210} \mathrm{~Pb}$ versus activity concentration of ${ }^{226} \mathrm{Ra}(\mathrm{Bq} / \mathrm{kg})$ and correlation coefficient between ${ }^{226} \mathrm{Ra}$ and ${ }^{228} \mathrm{Ra}$.

Points 1,2,3 presented a different pattern in the Ra-isotopes activity concentration when compared with ${ }^{210} \mathrm{~Pb}$. Point 12 presented high activities for all analysed nuclides. The high values measured in these points may reflect some influence from the proximity of Cubatão City. Furthermore, point 12 presented the highest organic matter concentration (about $24 \%$ as determined by calcination at $370^{\circ} \mathrm{C}$ ), which may explain such values.

Points 9,16 and 17, located at the end of the estuarine system, presented lower activity concentrations, probably due to higher dilution factors. These points are also located far from the industrial complex.

In Table 1 and figure 3 can be seen the activity ratios for ${ }^{226} \mathrm{Ra} /{ }^{210} \mathrm{~Pb}$ and ${ }^{226} \mathrm{Ra} /{ }^{228} \mathrm{Ra}$. The nuclides ${ }^{226} \mathrm{Ra}$ and ${ }^{210} \mathrm{~Pb}$ belongs to the ${ }^{238} \mathrm{U}$ decay series and ${ }^{228} \mathrm{Ra}$ to the ${ }^{232} \mathrm{Th}$ decay series. If the system is considered closed, all the radionuclides are in equilibrium and the activities of the daughter's nuclides are the same as the parent. In aquatic systems, on the other hand, the natural series are characterised by the lack of equilibrium [7], due to the different chemical properties and half-lives of the radionuclides.

If the experimental errors are taken into account, the activity ratios ${ }^{226} \mathrm{Ra} /{ }^{228} \mathrm{Ra}$ were close to unit in 8 of 13 analysed samples. The exemptions were samples 1,2 and 3 , for which the activity of ${ }^{226} \mathrm{Ra}$ was lower than ${ }^{228} \mathrm{Ra}$. The activity ratios ${ }^{226} \mathrm{Ra} /{ }^{210} \mathrm{~Pb}$ varied from $0.2 \pm 0.0$ to $0.5 \pm 0.1$, and only points 1,2 and 3 presented higher values, probably due to the antropogenic ${ }^{226} \mathrm{Ra}$. 


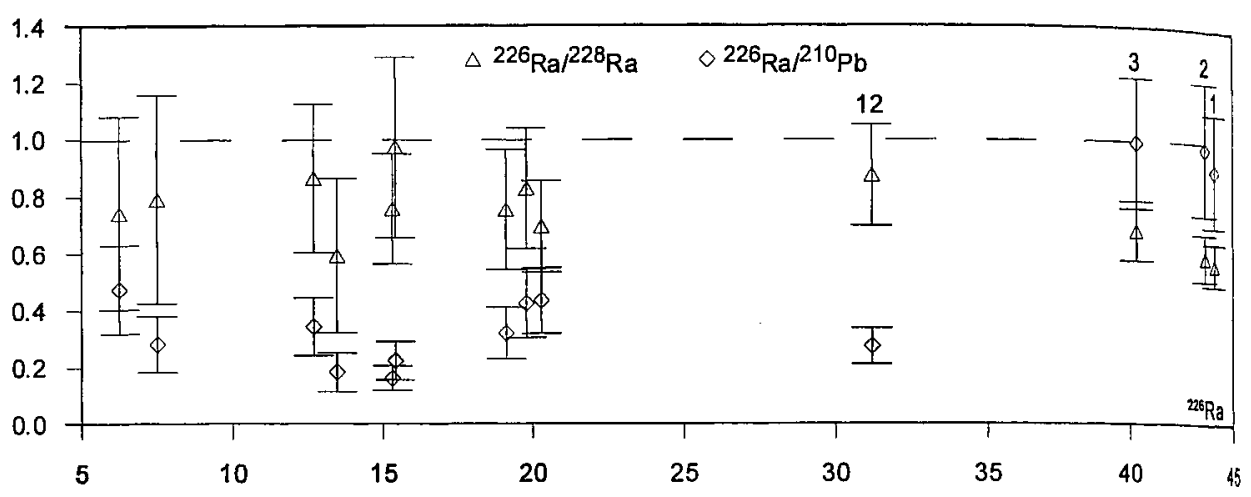

Figure 3: Activity concentration ratios ${ }^{226} \mathrm{Ra} /{ }^{228} \mathrm{Ra}$ and ${ }^{226} \mathrm{Ra} /{ }^{210} \mathrm{~Pb}$ for the analysed samples.

Table 1: Activity concentration of ${ }^{226} \mathrm{Ra},{ }^{228} \mathrm{Ra} \mathrm{e}^{210} \mathrm{~Pb}$ and isotopic ratios ${ }^{226} \mathrm{Ra} /{ }^{210} \mathrm{~Pb}$ and ${ }^{226} \mathrm{Ra} /{ }^{228} \mathrm{Ra}$.

\begin{tabular}{|c|c|c|c|c|c|}
\hline Sample & $226_{R a}$ & $228_{R a}$ & $210_{P b}$ & $226_{R a /} 210_{P b}$ & $226_{R a}{ }^{228} R a$ \\
\hline $\begin{array}{l}1 \\
2\end{array}$ & $\begin{array}{l}44 \pm 5 \\
43 \pm 5\end{array}$ & $\begin{array}{l}77 \pm 6 \\
73 \pm 6\end{array}$ & $\begin{array}{l}49 \pm 9 \\
44 \pm 9\end{array}$ & $\begin{array}{l}0,9 \pm 0,2 \\
1,1 \pm 0,3\end{array}$ & $\begin{array}{l}0,6 \pm 0,1 \\
0,6 \pm 0,1\end{array}$ \\
\hline 3 & $40 \pm 5$ & $59 \pm 6$ & $41 \pm 8$ & $1,0 \pm 0,2$ & $0,7 \pm 0,1$ \\
\hline 8 & $19 \pm 4$ & $25 \pm 5$ & $60 \pm 11$ & $0,3 \pm 0,1$ & $0,8 \pm 0,2$ \\
\hline 9 & $13 \pm 3$ & $15 \pm 3$ & $37 \pm 7$ & $0,4 \pm 0,1$ & $0,9 \pm 0,3$ \\
\hline 10 & $20 \pm 4$ & $29 \pm 4$ & $47 \pm 9$ & $0,5 \pm 0,1$ & $0,7 \pm 0,2$ \\
\hline 12 & $31 \pm 5$ & $36 \pm 5$ & $114 \pm 21$ & $0,3 \pm 0,1$ & $0,9 \pm 0,2$ \\
\hline 13 & $20 \pm 4$ & $24 \pm 4$ & $47 \pm 10$ & $0,5 \pm 0,1$ & $0,9 \pm 0,3$ \\
\hline 14 & $15 \pm 3$ & $20 \pm 3$ & $95 \pm 18$ & $0,2 \pm 0,0$ & $0,7 \pm 0,2$ \\
\hline 15 & $15 \pm 3$ & $16 \pm 4$ & $69 \pm 14$ & $0,3 \pm 0,1$ & $1,0 \pm 0,3$ \\
\hline 16 & $8 \pm 2$ & $10 \pm 3$ & $27 \pm 4$ & $0,4 \pm 0,1$ & $0,8 \pm 0,4$ \\
\hline 17 & $6 \pm 2$ & $8 \pm 3$ & $<13$ & $0,5 \pm 0,2$ & $0,7 \pm 0,4$ \\
\hline 21 & $13 \pm 5$ & $23 \pm 6$ & $73 \pm 8$ & $0,2 \pm 0,0$ & $0,6 \pm 0,3$ \\
\hline $\begin{array}{l}\text { MeantSD } \\
\text { RSD }\end{array}$ & $22 \pm \frac{13}{61}$ & $\frac{32}{74}$ & $5_{63} \pm 33$ & $0,5 \pm 0,3$ & $0,8 \pm 0,2$ \\
\hline
\end{tabular}

Mean $\pm \mathrm{SD}=$ arithmetic mean and standard deviation

$\mathrm{RSD}=$ relative standard deviation

In unperturbed sediment the activity ratio ${ }^{226} \mathrm{Ra} /{ }^{10} \mathrm{~Pb}$ is generally low because of incorporation of ${ }^{210} \mathrm{~Pb}$ from the solution, by adsorption on particulate matter, iron and/or manganese hydroxide $\mathrm{co}$. precipitation or by lead sulphate precipitation in anoxic water [8]. Beside that, ${ }^{210} \mathrm{~Pb}$ is in excess in many regions due to its formation in the atmosphere from ${ }^{222} \mathrm{Rn}$ (in a flux of 15 atoms $/ \mathrm{min} / \mathrm{cm}^{2}$ [9]), and subsequent incorporation in aerosols that are deposited in the water system. Ra activity decreases in the sediment by desorption process, due to its high solubility. In estuarine regions the influence of salinity in $\mathrm{Ra}$ desorption from sediment has been observed by the rising of $\mathrm{Ra}$ concentration in the overlying water. Moore, in his study in the Chesapeake Bay [10], showed that for a $0.5 \%$ salinity, about $12 \%$ of the ${ }^{226} \mathrm{Ra}$ are in the water in a soluble form and for a $5 \%$ salinity about $80 \%$ of the ${ }^{226} \mathrm{Ra}$ is in the dissolved form.

The relatively high values for the activity ratio ${ }^{226} \mathrm{Ra} /{ }^{210} \mathrm{~Pb}$ and low values for ${ }^{226} \mathrm{Ra} /{ }^{228} \mathrm{Ra}$ in points 1,2 and 3 shows an enrichment in the Ra isotopes in these points. To confirm this hypothesis, the results were submitted to a statistic treatment $[12,13]$, which indicates if a given data belongs or not to a given population, and the results corroborate a different pattern for these points. 
As organic matter is a good adsorbent of metals and radionuclides [14], its concentration was also determined in the sediments, by heating at $360^{\circ} \mathrm{C}-370^{\circ} \mathrm{C}$ for 2 hours. No correlation coefficient was found for organic carbon and ${ }^{226} \mathrm{Ra},{ }^{228} \mathrm{Ra}$ and ${ }^{210} \mathrm{~Pb}$ only for points 1,2 and 3 ; indicating a possible contamination in this area.

\section{CONCLUSION}

The ${ }^{226} \mathrm{Ra},{ }^{228} \mathrm{Ra}$ and ${ }^{210} \mathrm{~Pb}$ activity concentrations in the analysed sediments presented different behaviour in the estuarine and marine system. The results are quite well correlated with the amount of organic matter in the sediment. However, the relatively higher activities measured for ${ }^{226} \mathrm{Ra}$ and ${ }^{228} \mathrm{Ra}$ in points 1 , 2 and 3, which are located near the phosphate industries, may be explained by the presence of phosphogypsum in the nearby. This phosphogypsum, a by product of the phosphoric acid industry, is produced at a rate of 4000 tons per day and is stockpiled in open areas. According to Mazzilli et al. [15] approximately $90 \%$ of radium present in phosphatic rock migrate to phosphogypsum during the phosphoric acid production. This industrial activity may be responsible for this source of contamination.

\section{Acknowledgements}

This work was supported by Fundação de Amparo à Pesquisa do Estado de São Paulo - FAPESP, under fellowship contract 99/06952-4 and by Conselho Nacional de Desenvolvimento Científico e Tecnológico - CNPq, grant 300835/95-7. The samples analysed were provided by CETESB (Companhia de Tecnologia de Saneamento Ambiental).

\section{References}

[1] Cetesb - Companhia de Tecnologia de Saneamento Ambiental, Governo do Estado de São Paulo, Secretaria de Obras e do Meio Ambiente. 1978. Poluição da águas no estuário e baia de Santos V. 1.

[2] Cetesb - Companhia de Tecnologia de Saneamento Ambiental. 1981. Metais pesados na Baia de Santos e estuário de Santos e São Vicente.

[3] McNabb, G. J.; Kirk, J. A. and Thompson, J. L., 1979. Radionuclides from phosphate-ore-processing plants: the enviromental impact after 30 years of operation. Health Phisics, 37: $585-587$.

[4] Periáñez, R. and Garcia-León, M., 1993. Ra-isotopes around a phosphate fertilizer complex in an estuarine system at the southwest of Spain. Jour. of Radioanal. and Nucl. Chem., 172: $71-79$.

[5] InterWinner Spectroscopy Program Family Version 4.1 (release $1^{\text {st }}$ of June 1998) marca Eurisys Mesures.

[6] Custhall, N.H.; Larser, I. L. and Olsen, C.R., 1983. Direct analysis of ${ }^{210} \mathrm{~Pb}$ in sediment samples: selfabsorption corrections. Nuclear Instruments and methods 206: 309-312

[7] IAEA, 1990. The Environmental Behaviour of Radium, Technical Report Series No310, V. 1. Viena, $599 \mathrm{p}$

[8] Gascoyne, M., 1982. Geochemistry of the Actinides. In: Ivanovich, M and Harmon, R. S. Uranium Series Disequilibrium: Applications to Environmental Problems. Oxford, Clarendom Press, p. 33- 55.

[9] Rama; Koide, M. and Goldberg, E. D. 1982. Apud: Ivanovich, M and Harmon, R. S. Uranium Series Disequilibrium: Applications to Environmental Problems. Oxford, Clarendom Press, 571p.

[10] Moore, M. S., 1981. Radium isotopes in the Chesapeake Bay. Estuar. Coast Shelf. Sci. 12: 713-723.

[11] Molinara, J.; Snodgrss, W. J., 1990. The chemistry and radiochemistry of radium and the other elements of the uranium and thorium natural decay series, $11-56$, in IAEA, The Environmental Behaviour of Radium, Technical Report Series No310, vol. 1, Viena.

[12] Atalia, L. T., 1978. Interpretação Quantitativa de resultados experimentais, Instituto de Energia Atômica, 209p.

[13] Nalimov, V. V., 1963. The Application of Mathematical Statistics to Chemical Analysis, Pergamon Press, London, 294.

[14] Kralik, M., 1999. A rapid procedure for environmental sampling and evalution of polluted sediments. Appl. Geochem. 14:807-816.

[15] Mazzilli, B.; Palmiro, V.; Saueia, C. and Nisti, B. M., 2000. Radiochemical characterization of Brazilian phosphogypsum, Jour. of Environm. Radioactivity, 49: 113-122. 